UNIVERSITY OF CHITRAL JOURNAL OF LINGUISTICS AND LITERATURE

VOL. 5 | ISSUE I | JAN - JUNE | 2021

ISSN (E): 2663-1512, ISSN (P): 2617-3611

\title{
Celebrating Indigenous Culture and Identity in Bapsi Sidhwa's Ice Candy Man: A Postcolonial Critique
}

\author{
Zahid Abbas \\ (PhD Scholar), University of Sindh \\ zahidabbas0@gmail.com \\ Dr. Muhammad Tufail Chandio \\ Assistant Professor and Incharge Department of English, University of Sindh \\ mtufail@usindh.edu.pk
}

\begin{abstract}
To justify colonialism and perpetuate colonial rule the colonizers appropriated their political, cultural, academic, literary, and linguistic supremacy which left a tinge of mimicry and hybridity among the natives. The colonizers, being in the centre, employed colonial discourse, Eurocentric historic construct, Western education system, English language, missionary and creative literature to portray the periphery, the colonized, as uncivilized, accultured, incompetent, uncouth and diabolical evils. To rebut this, the postcolonial writers rejected colonialist ideology and cultural supremacy by asserting native culture, identity, language, and societal values. They disassociated themselves from cultural imperialism and celebrated their indigenous culture. This study analyses the portrayal of celebration of the indigenous culture and identity in Bapsi Sidhwa's novel Ice Candy Man (1988-89) from the vantage point of postcolonial theory. It has been found that Sidhwa celebrates indigenous culture, identity, tradition, language, and localization in the novel. To this effect, she employs code-mixing to add indigenous semantics, delineates characters from the locality, asserts her Pakistaniness and objectifies Pakistani leadership and narrative in the novel and thus she continues to live as a postcolonial writer.
\end{abstract}

Key words: celebration of indigenous, colonialist ideology, hybridity, identity, mimicry, oppression

\section{Introduction}

There is a projection of racial and cultural superiority in the Western colonialist ideology. The colonialist discourse asserts the superiority of the western civilization, culture, politics, education, and language system, which is rebutted by the contentions and tenets of 
UNIVERSITY OF CHITRAL JOURNAL OF LINGUISTICS AND LITERATURE

VOL. 5 | ISSUE I | JAN - JUNE | 2021

ISSN (E): 2663-1512, ISSN (P): 2617-3611

postcolonialism. Postcolonial writers project and celebrate their own indigenous culture, language, and identity. Bapsi Sidhwa, a Pakistani Parsi postcolonial writer of the Indian subcontinent, celebrates different aspects of her culture and identity in her debut novel Ice Candy Man (1988-1989). Set during the partition of the Indian subcontinent into two independent states i.e. Pakistan and India, the novel particularly celebrates local characters, local language and different dimensions of the character of Shanta.

\section{2. Research Questions}

The undertaken study aims at an in-depth analysis of the selected text of Ice Candy Man to answer following research questions from the vantage point of postcolonial literary discourse.

1. How does Sidhwa portray colonialist ideology, identity and culture in Ice Candy Man through characters?

2. How does the writer portray indigenous culture and identity in the selected novel?

3. How does the writer portray native characters in the selected novel?

\section{Literature Review}

A vast array of scholarship is available on Ice Candy Man. Shaheed (1991), being a connoisseur of the Indian subcontinent culture, critiques the novel from the perspectives of feminism and patriarchy. Similarly, Ehsan (2016) asserts that the novel deals with the various aspects of the land and culture, but the most important delineation is the destruction of human beings in history. Obviously, the destructive tone is very much explicit in the novel. Shahraz (2001) asserts that merely limiting the scope of the novel to the partition issue will be a misreading of the text. He adds that the novel has many nuances, and it invites modern readers to approach the text to explore the implicit aspects of the text. However, Syed (2004) has confined the scope of the novel to partition or feminist perspectives. Contrary to it, the present study aims to analyse and establish that Ice Candy Man is not merely limited to above mentioned issues, which in fact is a misreading of the novel. In order to fill the gap, the study aims to analyse how the issues such as celebration of the indigenous culture and identity are taken up in the text of the novel. 
UNIVERSITY OF CHITRAL JOURNAL OF LINGUISTICS AND LITERATURE

VOL. 5 | ISSUE I | JAN - JUNE | 2021

ISSN (E): 2663-1512, ISSN (P): 2617-3611

Marger (2000) is of the view that postcolonial theory also underpins the question of identity. Because of the colonial discourse and Eurocentric historical construct, the West stands at advantage in all walks of life even in literature whereas the depiction of colonized subjects in their texts remains compromised. It is the time, as asserted by Merger, that around the globe the supremacy of the west has been both admitted and questioned as well. Although the colonial era is ended yet the colonized identity still lingers on in ex-colonies. This identity of being colonized has influenced the colonized individuals in economic, social, religious as well as political spheres of life. The double-faced entry of colonizers in colonized territory is both volunteer and forced. At second point the colonizing powers influence the indigenous cultures by either altering them or destroying them completely. The third point is related to the colonized who tend to be governed by the colonial ideology. The crux of this entire phenomenon is that all these factors contribute towards governing the colonized by the dint of racist ideology coined and coerced by colonizers.

Memmi (1965) asserts that colonization and colonialism are actually about the supremacy and cultural hierarchy of the West. The metropolitan is considered to be the center of attention around the globe that is the form of colonization. The center holds the things and remains dominant in the world and rules over colonised territories. The rule of metropolitan is not for a specific period in different walks of life but for an extended period of time to rule over the entities called as "others". There are certain demarcations such as cultural, racial and political inequalities or economic and political dependence between the colonizers and colonized. The colonial ideology is maintained by different means and ways such as enslavement, occupation of native land, imposition of certain laws, use of physical force, exploitation of labour resources and also by objective murders which further means that colonisers do not have any emotional connections to the victims in colonised world, and thus celebrate the superiority of their indigenous culture over the colonized. However, the postcolonialism is diametrically opposite to the colonialism and it celebrates the indigenous cultures and makes colonized aware that they are not inferior to the colonizers in any walk of life and hence proving them to be equal to them.

\section{Methodology}


UNIVERSITY OF CHITRAL JOURNAL OF LINGUISTICS AND LITERATURE

VOL. 5 | ISSUE I | JAN - JUNE | 2021

ISSN (E): 2663-1512, ISSN (P): 2617-3611

The undertaken qualitative study has been conducted to analyse the portrayal of the celebration of indigenousness in Ice Candy Man from postcolonial theoretical perspective. The data have been reviewed from the text of the novel with the help of close-reading technique (Johnson, 2004; Kain, 1998). Close reading technique helps to deconstruct any phenomenon by analysing text from semantics, syntax, pragmatics, structure, narrative etc. point of view (McClennen, 2001). Since epistemologically the study belongs to constructivism therefore interpretivism has been used as a theoretical perspective to better analyse and understand the phenomenon undertaken for the study (Gray, 2004). The text of the novel will be reviewed to analyse the portrayal of the colonial ideology, culture, identity, the celebration of indigenous culture and identity and the delineation of native characters.

\section{Theoretical Framework}

The postcolonial literature refers to the literature written during or after the colonization, whereas the postcolonial theory re-examines the history of colonialism and presents the critique of the literature produced in the ex-colonies during and after the western colonization (Masood, 2019). To justify the act of colonisation, the colonizers produced literature to belittle, malign and manipulate the stature and stand of the colonized subjects and presented them as uncivilized, uncultured, uncouth, uncanny and unruly. To rebut this, the colonized launched the movements for freedom and independence. Besides, the literature they produced predominantly dealt with the questions of culture, identity, ethnicity, gender, race and all related to indigenous things (Conelly, 2000). Habib (2017) in his book Hegel and Empire: from Post colonialism to Globalism establishes that there are four fundamental aims of postcolonial theory. At first, it is to deal with the history of colonialism from the perspective of colonized. Secondly, it determines the influence in cultural, political, and economic sphere of life on both colonizers and colonized. Thirdly, the process of decolonization also falls under the category of postcolonial theory. The fourth point regarding the very nature of postcolonialism is the construction of identity from the perspective of colonization. Moreover, the participation in the political liberation goals, having equal access to material resources as well as circulation of cultural identities fall under the category of postcolonialism. 
UNIVERSITY OF CHITRAL JOURNAL OF LINGUISTICS AND LITERATURE

VOL. 5 | ISSUE I | JAN - JUNE | 2021

ISSN (E): 2663-1512, ISSN (P): 2617-3611

Donal Carbaugh (2001) relates the issue of identity as the most prominent theme and perspective in postcolonial theory. He asserts that a great deal of debate has been put about the effect of colonialism. Peters (2007) contends "at the season of decolonization, when imperial identities were decentred, the subject of identity became a basic and noticeable topic" (p.7). There is a link between Man's indigenous identity and his "self". This linkage or connection leaves the individual into the realm of instability. It leaves that individual into a space that belongs to nowhere or makes him and individual of having no place.

\section{Data Analysis and Discussion}

\subsection{The Portrayal of Colonialist Ideology, Superiority and British Culture in Ice Candy} Man

Sidhwa's fiction works basically deal with both pre and postcolonial period of the Indian subcontinent. She vividly portrays characters from the subcontinent with their complexities of life especially after the independence. One or the other way, Sidhwa has been considered to rewrite the history of the subcontinent presented from the Eurocentric perspective of British colonisation. Ice Candy Man grapples with the ground realities of the colonial world where the British colonizers celebrate their culture and treat the individuals of the colonized part of world as mere "others". According to Fanon's Wretched of the Earth (1963), the colonisers manipulate resources and consider human beings other than British as immoral, uneducated, uncivilized, and marginalized and much more that is negative in the strict sense of the word. Even, in Ice Candy Man it is depicted that the people living in the Indian subcontinent are not aware of what happens in their house. It is proved when Colonel Barucha during the clinical examination of a sick child enquires the father when the child has got cold. The father is completely ignorant and unaware of the facts. The doctor addresses the father, when father asks every single detail of the child from the mother, "she didn't, tell you? Are you a father or a barber? And you all want Pakistan? How will you govern a country when you don't know what goes on in your own house?" (Sidhwa, 1998, p.13). Colonel Barucha is a famous doctor and head of the local Parsi community. He treats Lenny, the narrator of the story, a poliostricken girl. Barucha is very critical of the people of his own community and more specifically the people of the subcontinent and considers them as incapable. They are meant to be slaves 
UNIVERSITY OF CHITRAL JOURNAL OF LINGUISTICS AND LITERATURE

VOL. 5 | ISSUE I | JAN - JUNE | 2021

and colonized as they do not have the capacity to govern and have a country of their own. The British or colonizers are with a mentality to rule and exploit. They are of the views that the movements for liberation and freedom from imperialism will end in smoke without yielding any fruit. It will bring chaos to their own world. This is evident in the claim of Col. Barucha who warns the Parsis of the consequences of Swaraj, "Hindus, Muslims and even the Sikhs are going to jockey for power: and if you jokers jump into the middle you'll be mingled into chutney!” (Sidhwa, 1998, p.34).

\subsection{Celebration of Parsi Perspective in Ice Candy Man}

Sidhwa's dealing with history is more complex than it appears in the novel. Being from the Parsi community, she rewrites the history not only from the Pakistani perspective but also from the Parsi perspective as well. While dealing with the history, she feels proud to be a Parsi and presents Parsi characters as witty and wise. She comments at time when the Parsi community was "kicked out of Persia" and they "sailed to India". After waiting for four days on the Indian coast they were visited by the Grand Vazir, with a glass of milk filled to the brim, symbolizing that the land was full and prosperous and in no need of "outsiders with different religion and alien ways to disturb the harmony." However, the Parsi forefathers, intelligently, "stirred a teaspoon of sugar into the milk and sent it back," symbolizing that the Parsis "would get absorbed into his country like sugar in the milk. And with their decency and industry sweeten the lives of his subject" (Sidhwa, 1998, p.27). This account establishes that how Parsi community got settled in India with their wit. Thus, the portrayal of their wit and intelligence in the novel marks the celebration of an indigenous trait. Contrary to the above discussion portraying a threat to the Parsi culture while getting absorbed in an alien culture, they remain true to their culture as well. They are found committed to their homeland culture even after getting assimilated into the host land culture.

\subsection{Celebration of Indigenous in Terms of Language}

Ashcroft et al. (1989) postulates that the indigenous writers employed English language, the language of the colonizers or centre, for twofold reasons: to deny its status as a sole metropolitan means of communication and to coin its new use, with reappropriation, to address the centre while recording their protest. While doing so, they abrogate its linguistic 
UNIVERSITY OF CHITRAL JOURNAL OF LINGUISTICS AND LITERATURE

VOL. 5 | ISSUE I | JAN - JUNE | 2021

ISSN (E): 2663-1512, ISSN (P): 2617-3611

standards, context and aesthetic sophistication. This "abrogation" and "appropriation" of linguistic phenomenon, which is termed as "Indigenous decolonization" is a logical repercussion of the colonialism, and the postcolonial writers employ it very effectively. Achebe contends, "I feel that the English language will be able to carry the weight of my African experience" (Whitekar \& Miska, 2007, p.47). Sidhwa's text is evident to this linguistic appropriation to convey the indigenous experience. She juxtaposes local semantics in her novel. The attempt to use indigenous words contains a mindful purpose that is to give importance to the native language. She makes the empire aware that writing in pure English has nothing to do with fame, popularity of work and its social acceptance. The use of indigenous words and language does not establish the inadequacy of Sidhwa's English language competence and acquisition. But she intentionally opts for this code mixing: "her eyes twinkling concern, in her grey going out "saari'" (Sidhwa, 1998, p.8). At another point in the novel she expresses, "a woman in a shabby black 'Burka' holds the child" (p.12). Similarly, "Far away I hear a siren tee-too" (p.21). The words like churails, little English Baba (p.25) "Angrez, shalwar kameez, array baba, dafa ho, bachao, badmash," are indigenous words which Sidhwa uses with much ease. She is not reluctant in using these words at all as they celebrate her indigenous thirst. At the same time, use of these indigenous words has twofold purposes: the first, to celebrates the indigenous culture, identity and language and the second, to convey a candid postcolonial message to the empire that she is never impressed by English language. The essence that the local word 'Badmash' implicates cannot be conveyed by 'robber' in English. Lenny comments, "Shanta bibi, you are Punjabi, aren't you? 'For the most part', Ayah agrees warily. "Then why don't you wear Punjabi clothes? I have never seen you in salwar-kamize" (Sidhwa, 1998, p.28). All these words are derived from the local language and hence it has been celebrated in the novel.

\subsection{Celebration of the Indigenous in Terms of Local Characters}

Sidhwa has delineated characters taken from the local culture and settings. They belong to Hindu, Muslim and Parsi communities. Lenny, the narrator of the novel, is a Parsi girl. She serves for the biographical references of Sidhwa herself and embodies symbolical Parsi presence. Shanta, the heroine of the novel, belongs to Hindu community. The word "Shanta" is 
UNIVERSITY OF CHITRAL JOURNAL OF LINGUISTICS AND LITERATURE

VOL. 5 | ISSUE I | JAN - JUNE | 2021

derived from the Hindi word Shanti which means peace. She embodies symbolical peace to many suitors irrespective of their castes and religions. She is equally loved by individuals of all communities. In addition, many other characters belong to indigenous Muslim, Hindu and Parsi communities, and they take pride in celebrating their communal rites, cultural rituals and traditions of the subcontinent. The character of Ice Candy Man represents every Tom, Dick and Harry as he is a Popsicle seller, whose presence is phenomenal at every local premise.

\subsection{Sidhwa's Portrayal of Pakistani Perspective in Ice Candy Man}

Sidhwa presents an indigenous Pakistani perspective in Ice Candy Man. The agenda that has been pinpointed in the novel was expressed earlier in an interview with David Montenegro where Sidhwa illustrated that literature on the partition of the subcontinent written by either British or Indian writers was tinged with personal bias. She reiterated that those writers were basically unfair to Pakistan. Given to the injustice and bias, Sidhwa took her pen to remove these marks of unfairness and partiality. She asserted that facts always speak themselves and she found the real facts and presented her experiences in Ice Candy Man. The unfairness to Pakistanis, distorted portrayal of Muslims and misrepresentation of history are the factors Sidhwa seems highly concerned about. She not only questions and refutes the validity of negative labels attached to Pakistani national heroes, but she also vividly highlights the duality of Indians. The leaders like Quaid-e-Azam are celebrated for their commitment and vision in the text that shows Sidhwa is very much ceremonial of her Pakistani roots. She shows Jinnah saying, "You are free. You are free to go to your temples, your mosque, or any other place of worship in the state of Pakistan. You may belong to any religion or caste or creed that has nothing to do with the business of state...etc...etc...Pakistan Zindabad!” (Sidhwa, 1998, p.144). This establishes her affiliation with Pakistan and her take on regarding the Pakistani perspective in Ice Candy Man.

\subsection{Celebrating the Character of Jinnah and Demystifying Nehru and Gandhi}

It has been noticed that the British and Indian historians have neglected the character of Jinnah and celebrated Hindu indigenous heroes. They have mystified the images of Gandhi and Nehru. However, Ice Candy Man demystifies these characters and Jinnah has been revived and celebrated. The text of Ice Candy Man reveals that sublime image of Gandhi has been 
UNIVERSITY OF CHITRAL JOURNAL OF LINGUISTICS AND LITERATURE

VOL. 5 | ISSUE I | JAN - JUNE | 2021

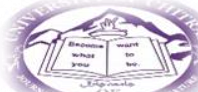

ISSN (E): 2663-1512, ISSN (P): 2617-3611

totally undercut against the construction of British and Indian historians. When he is seen through the eyes of seven years old polio-stricken girl, "he is small, dark, shriveled, and old. He looks just like Hari, our gardener, except he has a disgruntled, disgusted and irritable look; and no one would dare pull his dhoti!" (Sidhwa, 1998, p.42). This image is totally against the portrayal of Gandhi in British discourse. There, he is presented as a political figure and tycoon of politics. But the celebration of indigenous culture, being a Pakistani, living in Muslim country founded by Jinnah it is unbearable for Sidhwa to accept the image presented by Indians and English. Similarly, character of Nehru is nothing but a shrewd person. The seven years old narrator finds Nehru as a "a shrewd politician who despite all the efforts of Jinnah will walk off with lion's share. He is a sly one. He's got Mountbatten eating out of his one hand and English's wife out of his other what not.... He's the one to watch" (Sidhwa, 1998, p.35). The image of Jinnah has been restored as a national hero and liberator against those negative images presented in Indian and English books. Thus, Ice Candy Man essentializes the celebration of local heroes who have long been ignored or othered.

\subsection{Celebrating Parsi-Muslim Relationship in Ice Candy Man}

Sidhwa neutralizes the depiction of historical facts in Ice Candy Man. She puts the burden of bloodshed, violence and atrocities inflicted upon the migrating people equally on the shoulders of Hindus, Muslims, and Sikhs. However, she establishes that it was not Muslims who initiated violence or bloodshed, but they reciprocated after being the victims. Being a Pakistani writer, her sympathies are with Muslim victims. The attack on Muslim villages by Sikhs in Punjab is seen through the eyes of a Muslim child Rana, it invokes empathy and compassion for Muslims. In an interview with David Montenegro (1990), Sidhwa observes, "The Sikhs perpetrated the much greater brutality they wanted Punjab to be divided. A peasant is rooted in his soil. The only way to uproot him was to kill him or scare him out of his wits" (Sidhwa, 1998, p.51). She is very candid, and her sympathies are with Muslims rather than with any other community and she celebrates her Pakistaniness. Jajja (2012) establishes that Ice Candy Man can be coined as 'an attempt' to present Pakistani perspective by a Parsi writer that shows her inclination towards Muslim community and her sympathy and compassion for Muslims. At the same time the brutality inflicted on the Muslims during migration reflects her 
UNIVERSITY OF CHITRAL JOURNAL OF LINGUISTICS AND LITERATURE

VOL. 5 | ISSUE I | JAN - JUNE | 2021

ISSN (E): 2663-1512, ISSN (P): 2617-3611

objectively sympathetic outlook towards the Muslim community. Sidhwa illustrates, "A train from Gurudaspur has just come in... Everyone in it is dead butchered. They are all Muslim" (Sidhwa, 1998, p.149).

\subsection{Sidhwa's Justification for Writing in the Language of Colonizers}

When Sidhwa's writings are analysed from the postcolonial perspective, a feature that celebrates indigenous language and justifies the use of English is very interesting. The language is the basic preoccupation of colonizers when it is chosen for writing a discourse. This element is nothing but reverence for colonizer's language by neglecting the local languages. Writing in the language of colonizers gives a great deal of range for social acceptance as a writer. The stance provided by Chinua Achebe and Ngugi is worth mentioning as both write in English vernacular. Ngugi, in his earlier works used to write in English language but later he left writing in English and switched to the native language. Ngugi puts forward some reasons for preferring the native language to English: "Language has always been used by colonizers to mentally and spiritually control colonized. The mental universe of colonized is dominated due to crucial weapon of language" (Ngugi, 2004, p. 22). He further argues that by continuously writing in the language of colonizers one is colonized on cultural level and enriches the European cultures instead of enriching his own. But point of view presented by African writer Achebe who agrees with Thiong'o when he argues, "I feel that the English language will be able to carry the weight of my African experience. But it will be a new English with the full communion of ancestral home" (Thiong'o, p.286). The same assumption of Achebe applies to the writings of Sidhwa who uses English with full communion of ancestral home. Her English is new with the code mixing of indigenous words. There is indigenous touch in her use of English language, which shows her love for locality and mother language. She leaves several words as untranslated from the native language such as "pahailwan, a wrestler", "Choorail, witch", "Shabash, well-done!", "GharkiMurgi dal barabar, a neighbour's beans are tastier than house-hold chickens", "Khutputli, puppet", "Mamajee, uncle". These words are basically cultural signs. For example, the word of Kotha that is translated as roof but is a place of prostitutes. There is gap between the two words of Kotha and roof so Sidhwa uses the local words to maintain their essence. The 
UNIVERSITY OF CHITRAL JOURNAL OF LINGUISTICS AND LITERATURE

VOL. 5 | ISSUE I | JAN - JUNE | 2021

ISSN (E): 2663-1512, ISSN (P): 2617-3611

untranslated words are part of the strategy of the postcolonial writers to highlight the cultural difference.

\subsection{Celebration of Muslim Culture and Poetry in Ice Candy Man}

In postcolonial terms, various strategies have been adopted to celebrate indigenous traits. It is noteworthy to portray that the novel Ice Candy Man also celebrates the Muslim culture as well. The text of the novel is rich with multiple quotes from Urdu poets. Even the novel opens with the verse of Iqbal's poem Shikwa (A Complaint to God). The lines are:

"Shall I hear the lament of nightingale, submissively lending my ear?

Am I the rose to suffer its cry in silence years after year?

The fire of verse gives me courage and bids me no more to be faint

With dust in my mouth I am abject: to God I make complaint

Sometimes you favour our rivals then sometimes with us you are free

I am sorry to say it so boldly. You are no less fickle than me" (Sidhwa, 1998, p.1)

These quotes portray anticolonial stance and love for local cultures and climate. The lines from Iqbal's poetry at the beginning of the chapter thirteen of Ice Candy Man are:

"The times have changed; the world has changed its mind

The European's mystery is erased

The secret of his conjuring tricks is known

The Frankish wizard stands and looks amazed" (Sidhwa, 1998, p. 107)

Sidhwa's love for poetry, especially of Muslim poets represents that she is more inclined towards the portrayal of Muslim culture in their literature. On the other hand, this inclination reflects that the novel Ice Candy Man celebrates Muslim culture and portrays it as rational, inspirational, and related to its civilization.

\section{Conclusion}

The study unfolds how Ice Candy Man celebrates the indigenous culture, language, custom and belief system. Sidhwa has successfully questioned the version of subcontinent, the partition, Pakistan, Jinnah, and the ways of living of individuals provided by Indian and British historians. She has presented an alternate version of history based on her own perspective 
UNIVERSITY OF CHITRAL JOURNAL OF LINGUISTICS AND LITERATURE

VOL. 5 | ISSUE I | JAN - JUNE | 2021

ISSN (E): 2663-1512, ISSN (P): 2617-3611

mainly Pakistani. She pays tribute to the Muslim poets like Iqbal and celebrates their sublimity of thought. She uses the local language and original words with their local and indigenous essence. Moreover, using English vernacular is justified when she loads this language with her experiences of history. She celebrates her own identity as being Parsi and advocates the whole Parsi community and feels proud to be an individual from a witty nation. Her writing is tinted with compassion for Muslims who endured the atrocities of the partition, and she deeply owns their loss and pain. The portrayal of local and indigenous characters shows that she is inclined towards the native locality. She loves peace and condemns the chaos and violence taking place at the time of partition. She cannot see individuals being humiliated, dragged, and ultimately killed especially Muslims. In all respects, she celebrates her local things and rejects the colonial mindset rather criticizes their mentality. The portrayal of local masses as colonized, periphery and marginalized is same as they are being judged in unfavourable light and prison. Sidhwa in this sense has done a great job as she has given them a tongue that helps them to assert their own identity. She makes the West aware by her use of indigenous things that those whom they think as colonized are not worthless. Moreover, they are vocal and candid to argue and claim their identity as well as inherited indigenous civilization.

\section{References}

Ashcroft, B., Griffiths, G., \& Tiffin, H. (1989). The Empire Writes Back. London and New York.

Carbaugh, D., Berry, M., \& Nurmikari-Berry, M. (2006). Coding personhood through cultural terms and practices: Silence and quietude as a Finnish "natural way of being". Journal of Language and Social Psychology, 25(3), 203-220.

Gray, D. E. (2004). Doing research in the real world. SAGE.

Habib, M. A. R. (2017). Hegel and empire: From postcolonialism to globalism. Springer.

Jajja, M. A. (2012). Sidhwa's Portrayal of the Partition: An Independent Perspective. Journal of Educational Research 15 (2), 1027-9776.

Johnson, R. (2004). What is Close Reading? Mantex.

Juneja, O. P., Salat, M. F., \& Mohan, C. (1991). Looking at our particular world: An interview with Rudy Wiebe. 
UNIVERSITY OF CHITRAL JOURNAL OF LINGUISTICS AND LITERATURE

VOL. 5 | ISSUE I | JAN - JUNE | 2021

Kain, P. (1998). How to Do a Close Reading. Writing Center at Harvard University.

Kraus, W. (2006). The narrative negotiation of identity and belonging. Narrative Inquiry, 16(1), 103-111.

Marger, M. N. (2014). Race and ethnic relations: American and global perspectives. Cengage Learning.

McClennen, S. A. (2001). How to Do a Close Reading. Dr. McClennen’s Close Reading Guide. The Pennsylvania State University.

Memmi, A. (2013). The colonizer and the colonized. Routledge.

Montenegro, D., \& Sidhwa, B. (1990). Bapsi Sidhwa: an interview. The Massachusetts Review, 31(4), 513-533.

Pozo, M. (2004). An Interview with Ngugi wa Thiong'o. St. John's University Humanities Review, 2.

Rowell, C. H. (1990). An Interview with Chinua Achebe. Callaloo, 13(1), 86-101.

Shaheed, F. (1991). The cultural articulation of patriarchy. In F. Zafar (Eds.), Finding our way: Readings on women in Pakistan (pp.135-158). Pakistan: ASR Publications.

Shahraz, Q. (2001). The holy woman. Pakistan: Black Amber Books.

Shahraz, Q. (2003). Typhoon. London: Black Amber Books Limited.

Sidhwa, B. (1998). Ice Candy Man. India: Penguin Books Ltd.

Spivak, C. G. (1999). A critique of post-colonial reason: Towards a history of the vanishing present. Cambridge: Harvard University Press.

Syed, A. (2004). These codes of honour. DAWN.

Thiong'o, N. (1992). Decolonising the mind: The politics of language in African literature. East African Publishers.

Thiong'o, N. (2004). Beyond nativism: an interview with Ngùgî wa Thiong'o. Research in African Literatures, 161-167.

\begin{tabular}{|c|c|}
\hline 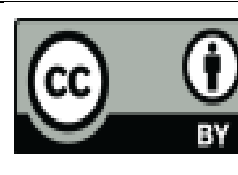 & $\begin{array}{l}\text { @ } 2021 \text { by the author. Licensee University of Chitral, Journal of } \\
\text { Linguistics \& Literature, Pakistan. This article is an open access article } \\
\text { distributed under the terms and conditions of the Creative Commons } \\
\text { Attribution (CC BY) (http://creativecommons.org/licenses/by/4.0/). }\end{array}$ \\
\hline
\end{tabular}

